'Snatched by Destiny's Hand':

Obituaries and the Making of Class in Modern Egypt

Hussein A H Omar 


\begin{abstract}
$\underline{\text { Abstract }}$
This article examines the newspaper obituary as a source for historians of latenineteenth and early twentieth-century Egypt. Long utilized by genealogists, these sources have been neglected by historians, for a number of reasons. Rather than read them as an uncritical reflection of social relations, as genealogists have, historians ought to engage with them critically as a way of understanding how individuals imagined themselves and their social worlds.
\end{abstract}

The article argues that reading and writing obituaries was one of the ways in which a previously differentiated and divided Egyptian elite began to imagine itself as belonging to a single, horizontal class. It further demonstrates how obituaries can be used to chart social mobility in a context where surnames were neither heritable nor standardised. Obituaries provide unique insights into social sociocultural transformations independent of the political ruptures around which state archives are organised and official histories written. The article shows how sociocultural developments (such as the rise of Islamic modernism) are reflected in, and were transformed through, the reading and writing of obituaries. Discourses around the 'good Muslim death' were inscribed and indeed prescribed through this form, even as it came under increasing attack at the turn of the twentieth century for being unIslamic. Aside from opening up new methodological avenues for writing the history of class, and the history of gender beyond the state, the article emphasises the importance of death as a historical subject of enquiry in its own right. 


\section{'Snatched by Destiny's Hand': Obituaries and the Making of Class in Modern Egypt ${ }^{1}$}

It was said in Cairo that 'a person cannot have died if their death goes unmentioned in Al-Ahram'. ${ }^{2}$ On the pages of Egypt's preeminent newspaper, the death notices span over thirty columns, providing a comprehensive necrographic record of each day. Cairo's ladies of leisure, one journalist observed, would turn straight to the 'intriguingly thorough' obituary section at the back of the paper each morning to plan their daily schedule of condolence visits. The notices - which listed ever more distant members of the bereaved family, along with 'the knotted web' of alliances that bound them together-were a precious resource for this sepulchral set, known to drop anything for a funeral. ${ }^{3}$

My father, too, always read the paper back to front, but for a different reason: the obituaries were the only news he believed to be reliable. Amid censored texts, doctored images and the unremitting propaganda produced by a succession of autocratic regimes, death was the only certainty in Egypt's state-sponsored newspapers. But with certainty comes banality: empty of biography and featuring little more than a string of names and social relations, the obituaries seem to hold little of value, unless one were a genealogist or a socialite planning the day's round of condolences. It is unsurprising, then, that professional historians of Egypt have seen little reason to turn to al-Ahram's back pages.

Fixated on the 'properly archival', professional historians have paid little attention to alternative forms of knowledge about the past such as genealogy, and its sources and methods. Seeking to demarcate as well as police the lines between History (with a capital ' $\mathrm{H}$ ') and its many siblings, historians have ignored obituaries, consigning them to the progonoplexic genealogist's trivial and nostalgic domain. ${ }^{4}$ Yet I would argue that they are perhaps more useful for the historian than for the genealogist. For genealogists who read them as straightforward and accurate records of familial relations, death notices can be misleading, as I will show. But for the historian, by contrast, they are a uniquely penetrating source. Far from being unmediated and 
transparent documents that merely list names, titles and dates, obituaries are rich literary texts that not only reflect significant sociocultural transformations, but also were themselves vehicles for disseminating important ideas. Examined carefully, they reveal the ways in which individuals imagined and represented themselves and their social worlds, mirroring some of the most salient sociocultural transformations in late-nineteenth and twentieth-century Egypt. Sitting at the intersection of the documentary and the literary, obituaries were a form of life-writing. They drew on older classical genres (such as the tabaqat) but also channeled the same impulses towards immortality and memorialisation that made the writing of diaries, memoirs and autobiographies explode onto the literary landscape of Egypt in the late nineteenth century. Obituaries were the textual articulations of the material changes that had transformed the Egyptian elite into a distinct class; they were verbal social maps that placed their readers and writers in the newly classed national landscape. They were also, as I will show, vehicles for inscribing new ethical ideals, typically described as 'Islamic modernist' and associated with elites. It was through the mediation of mundane texts like obituaries that these ideals were communicated and became hegemonic. And it is by examining these texts that new avenues for intellectual history emerge. They allow us to think about the mediation of new intellectual and political developments beyond the theological treatises, speculative and abstract, of great men (such as those of Muhammad 'Abduh, for example), which have long cast their heavy shadows, distorting intellectual histories of the region.

Although the prosopographical data contained in newspaper obituaries may at first seem identical to that found in census, tax registry, shari'a court and inheritance records, there are notable if subtle differences. It is notoriously difficult to gain access to the latter type of record, as they are held in the heavily policed Registry and Property Archives and the National Archives. Despite efforts to make these institutions more transparent, they remain badly organised, and access to them is restricted by draconian security regulations that put them out of bounds to all but a select few. ${ }^{5}$ But even if accessibility were not a problem, the obituaries - composed by 'ordinary' people, albeit mostly of certain means — offer alternative modes of selfrepresentation than those in the records produced, edited and curated by state bureaucrats and archivists. ${ }^{6}$ Written by relatives of the deceased, obituaries speak from the perspective of individuals and their families: how and with whom they 
wished to be identified, as well as what features they thought to be important about themselves. They also show that heritable patronyms were adopted in a place like Egypt by individuals and families before the state made them compulsory by law (as in the much more well-known case of Turkey). By examining obituaries instead of archival records, historians can investigate how elites self-identified beyond and outside the impositions of the state and its laws. ${ }^{7}$ Obituaries, then, allow scholars to recover histories of class formation, surname adoption and the emergence of the bourgeois family unit, independent of the usual models of state imposition and resistance.

As I argue, the obituary form and its evolution are worthy of study as a subject in itself. It provides insights into what might otherwise be less visible in a state archive - such as the changing nature of gender, communal and class relations. Regarding gender, for example, the names of women were often omitted from their own obituaries, being simply identified by their relation to their male relatives ('wife of', 'daughter of', 'mother of', or 'sister of'). In general, non-Muslim women were more frequently named than their Muslim peers, as were members of the vice-regal or Ottoman imperial family, but this was not always the case. ${ }^{8}$ Who were these women, and what did the choice to name or not name them signify? In some cases, women were not named in obituaries but were named on their cenotaphs or in lists of donors to the various philanthropic organisations that proliferated in the late nineteenth century. ${ }^{9}$ What kind of women were named and how the answer to this question changes over time lie beyond the scope of this article but suggest fascinating avenues for further investigation.

One might also look to the obituaries, and in particular to the forms of address that non-Muslims used to identify themselves with from the 1870 s to the 1960 s, in order to examine evolving communal relations. Forms of address such as 'al-Mu'allim' and 'al-Khawaga' were both used in obituaries to identify Christians throughout the century, but how these forms of address overlapped and how they were distinct might be gleaned from a more systematic study of the obituaries. Likewise, in obituaries Christian women were often addressed by forms such as 'al-Khatun', a Persianate honorific that in the past did not have Christian connotations, but which by the late nineteenth century would be associated exclusively with Christian women of high 
standing. Likewise in obituaries, non-Muslim women were often addressed by forms such as 'al-Khatun', a Persianate honorific that in the past did not have sectarian connotations, but which by the late 19th century would be associated mostly with non-Muslim women of high standing. Why such forms of identification were common in an age frequently characterised as 'secular' and why they would disappear in the postcolonial period is worthy of exploration and provides insights into the evolving nature of communal relations.

The questions that the obituaries pose are myriad; in what follows I will focus only on a small selection. In the first half of this study, I will look at the obituaries as source, examining what they tell us about class, and how they may help transcend rigid and simplistic academic taxonomies that are frequently deployed to make sense of it. ${ }^{10}$ In a society in which neither patronyms nor titles were necessarily heritable, obituaries provide a unique source for tracing and understanding social mobility. In the second half, I will examine obituaries as a subject of controversy in their own right, and trace how at the turn of the twentieth century they became vehicles for Islamic modernist reformers to disseminate novel moral norms.

Obituaries are as old as the newspaper industry itself in Egypt. Al-Ahram's very first issue, in August 1876, carried on its back page the announcement of the death of a certain 'Irfan Pasha, who had been buried a few days before. Apart from conveying that he had been an overseer of the agricultural estates of Prince Tusun, the obituary says little about the deceased — not even his full name. 'No doubt', the unnamed author writes, 'all will be aware of his pleasing morals, his praiseworthy qualities, his honesty, his complete trustworthiness. ${ }^{11}$ Published as a news item amid other local reports, Egypt's first obituary was fairly sparse in information, if overwrought with approbation. The form of the obituary might have been novel, but it drew on an established wellspring of idioms. The platitudes ascribed to the deceased would have been familiar to readers, as they recalled a much older genre, the classical Arabic biographical dictionaries (tabaqat). Here, however, the author addresses his readers in the familiar second person, a reminder of the minuteness of the paper's early readership. Wired in by correspondents in the Ottoman Empire's various provinces, 
the obituaries communicated telegraphic reports of the deaths of individuals deemed newsworthy, a category that was neither established nor stable in those early years. In 1877, the paper's second year, this included a sharif of Mecca and Zaynab Hanim, the daughter of an Egyptian foreign minister. ${ }^{12}$ But beyond indicating whom it was that Egypt's first generation of journalists deemed newsworthy, these reports offer little historical insight.

Rather it is to the paid advertisements, written by relatives not reporters, that our attention must turn. Although it is unclear when people began paying for such notices in Egypt's papers, by the first decade of the twentieth century the expensive practice had become firmly entrenched among literate elites. By mid-century, death announcements spanned three dedicated pages of the newspaper. The notices, charged per line of text, could be staggeringly detailed, not only listing the names of the deceased, but also those of their parents, children, siblings, grandchildren, uncles, aunts, cousins, grandparents and ever more distant ancestors. Even today, at a time when few print papers, in Egypt or elsewhere, are profitable, al-Ahram is rumoured to break even thanks to its death notices. ${ }^{13}$ In addition, in the days following the announcement, individuals typically published personalised notes of condolence to the family, and the family responded with notes of thanks. In 1954, it cost twenty piasters per five-word line. ${ }^{14}$ In 2014, it cost 180 Egyptian pounds per line of death announcement, and 192 pounds per line to publish a response. A photograph cost four times as much. ${ }^{15}$ That families have gone to such trouble, financial or otherwise, to have these notices published poses the question as to what they represent, and why this novel form became so popular.

Historically, the function of a death notice differed depending on whether it was published by a Muslim or Christian family. For Christians, the authors of a disproportionately large fraction of the obituaries, death notices announced an impending funeral, memorial service or receptions of condolences at home. They often provided the home address of the deceased to which formal telegrams could be sent. The obituaries of Muslims, however, appeared at some distance in time from both burial and funeral. The fact that the newspaper in its early years was only a weekly publication and that Muslims typically bury their deceased on the day of, or immediately after, the death, suggests that the obituaries had a function beyond the 
self-evident purpose of announcing condolence receptions. Some obituaries stated explicitly that the family would not be receiving condolences beyond the day of burial, which had already passed. Furthermore, from the 1950s onwards the names of dead relatives were usually also included. ${ }^{16}$ The exhaustive list of social relations, as well as the increasingly complex and precise language used to describe them, went beyond the simple purpose of identifying the dead and announcing their funerals.

Obituaries situated their readers, and located their writers, within a vast social network of families that was, by the early decades of the twentieth century, congealing into something of a distinct socioeconomic class. Generically referred to as 'elites' in the academic literature, the producers and consumers of obituaries frequently described themselves by the more precise labels of $a$ 'yan (notability) or dhawat (aristocracy), even if they used them interchangeably at times. ${ }^{17}$ Reading and writing obituaries was one way through which people who did not know one another directly could begin to imagine themselves as belonging to the same national, horizontally conceived community — an identification which would override local, vertical and even ethnic affinities. After titles were abolished in August 1952, following the Free Officers' coup, obituaries developed ever more sophisticated codes for socially situating the dead; texts grew longer and the elaboration of relations more intricate. As such, no obituary is self-contained or discrete, but instead points sideways, embedding both reader and writer in a large network of social relations. In highlighting such hidden and labyrinthine links between individuals-connections that would be invisible on an amble among the walled mausolea of Cairo's vast necropolises - it forged its readers' consciousness as a class. ${ }^{18}$

Up until the mid-twentieth century, the obituaries commonly omitted the names of deceased women and children, and contained very little biographical data. ${ }^{19}$ Instead they teemed with the names (and more rarely, professions) of the living, and with exegeses of the complex relations that bound them to one another. These family biographies were not always intended to be taken as an accurate representation of real familial relations. At once constitutive and performative, obituaries sometimes posited fictive relations between individuals - the genealogist, therefore, must tread with care. For instance, one obituary describes the deceased as the grandson of nationalist hero Sa'd Zaghlul. ${ }^{20}$ The proverbial 'Father of the Nation', Zaghlul was father to no man; 
readers would have understood that the deceased was not his actual grandson, but a distant younger relative. The decision therefore to include or exclude relatives was crucial, not only reflecting class belonging but more importantly, projecting social ambition.

Further confounding the genealogist, sometimes obituaries announced deaths that had not occurred. Family members were known to have falsely reported the death of a relative - the wealthier, the better - for inheritance purposes. In March 1895, alAhram published the following note:

We received a letter stamped with the seal of a man named Mahmud Ibrahim ... announcing the death of the honorable doctor, Hassan Bey Rifqi, and calling upon us to publish the news of his death, alongside a note of thanks to the condolers. We published the announcement ..., but it appears to us today — and thank god — that the news is untrue. ... We ask the aforementioned doctor to forgive us. ${ }^{21}$

Three days later, the government imposed a hefty fine on the perpetrator. ${ }^{22}$

Genealogically intricate obituaries allowed individuals to situate themselves within an imagined socioeconomic community-establishing proximity to some and distance from others - at a time when the use of heritable patronyms was far from the norm. Like many in the premodern world, Egyptians seldom used fixed, hereditary surnames before the late nineteenth century. As James C. Scott has argued for other contexts, inherited familial surnames are a relatively modern invention tied to the extension of state control, as well as to the development of modern legal and property regimes. ${ }^{23}$ Designed to make individuals and their relations more 'legible' to the eyes of the state, inheritable surnames were imposed with some degree of force; the case of the Turkish surname law of 1934 is the most notable. ${ }^{24}$ Yet by looking at obituaries - as opposed to state-produced archival sources - a different picture emerges from that proposed by Scott.

Unlike the baptismally bestowed Christian names and heritable surnames of modern 
Europe, Egypt's local system of naming, common across the premodern Islamicate, was complex and descriptive. Apart from the given name, all other names had a descriptive function, suggesting an individual's parentage, their place of origin and, where relevant, the name of their firstborn as well as their professional or physical attributes. A long chain of paternal ancestors' names identified an individual genealogically. ${ }^{25}$ But because their function was descriptive, these names were neither absolute nor heritable; rather, they were locally and relatively determined. In Istanbul, for example, an individual might be identified as 'so-and-so the Egyptian' because they had been born in Egypt, whereas in Cairo, they may be known as 'the Circassian' because their ancestors were Circassian. ${ }^{26}$ It was this instability that, Scott argues, made it incumbent upon modern legal property regimes to impose heritable patronymics. And at first Scott's hypothesis does seem to prove true. Khaled Fahmy has shown that it was legal changes in the mid-nineteenth century that forced litigants and witnesses to identify themselves in the courts of law as so-and-so the daughter of so-and-so. These novel changes not only made legal equality for the first time possible but also wrought a 'transformation in the very notion of the individual'. ${ }^{27}$ Yet these practices of legal identification by patronym, described by Fahmy, were not heritable, nor were these methods of identification used in all domains of officialdom and in all state institutions. As we will see, individuals also adopted their mother's surnames, outside of the courts of law, even after the legal transformations that Fahmy described.

The emergence of heritable patronyms seems to have been the product of more than straightforward imposition by law. For example, it was often state agents like schoolteachers that attempted to erase heritable patronyms from young boys' names, and it was 'ordinary' Egyptians that insisted on retaining them. From the early decades of the nineteenth century, the schoolmasters of the new state schools frequently assigned their pupils two-part names that had little to do with either the descriptive Islamicate system described above, or with the practice of adopting heritable patronyms in the other contexts that Scott examines. ${ }^{28}$ This allegedly meritocratic measure concealed boys' paternal origins and was supposed to enable social and professional mobility within the expanding state bureaucracy. Much like Islamic inheritance practices that divided property equally among male sons, the adoption of an arbitrary set of two given names was understood to be a social leveller 
that would help prevent the formation of local dynasties and eliminate class privilege. But far from being welcomed, Egyptian elite figures denounced this 'Turkish' innovation as yet another form of resented state violence that eliminated boys' connections to their historic, familial and local roots. ${ }^{29}$ The politician Fathalla Barakat Pasha recalled how a schoolmaster assigned him a name, Fathalla Zaki, eliminating the patronymic (laqab, plural: alqab) 'Barakat' that his family had used for centuries. He described how his cousin Ahmad Fathi Zaghlul, the eminent translator, was forced to abandon his laqab 'Zaghlul' and rename himself Fathalla Sabri. Both, upon departure from the school, reverted to their original names in rebellion. ${ }^{30}$

Even as some tried to resist such measures, renaming at school was often successful. This meant that brothers, fathers, sons and paternal cousins often did not bear the same last names as one another. Examining a number of obituaries one can see how prevalent this practice was among highly prominent historical figures: Isma'il Sidqi Pasha (son of Ahmad Shukri Pasha); Husayn Rushdi Pasha (son of Mahmud Hamdi Tapuzada Pasha); Muhammad Mahmud Pasha (son of Mahmud Sulayman Pasha); Ahmad Hishmat Pasha (son of Shaykh Hijazi 'Umar); and 'Abd al-Aziz Fahmi Pasha (son of Hijazi 'Umar Bey). ${ }^{31}$ The obituaries of these people born before birth certificates became compulsory, or even popular, make visible connections between fathers and sons who, on the basis of names alone, might have otherwise appeared unrelated.

Seeing these connections through obituaries we can also learn about naming practices - such as the adoption of matronyms - that are invisible in official archives and that would all but disappear. The case of the family of Mustafa Bahgat Pasha, minister of public works, is instructive. ${ }^{32}$ The eldest of Bahgat's daughters, Zuhra, gave her son his maternal grandfather's surname, since there were no other male heirs to carry the illustrious name forward. ${ }^{33}$ In the very same manner, Zuhra's daughter Latifa, named her own son, Isma‘il Bey Mazhar-Darwin’s first Egyptian translator - after the family of her own father Muhammad Mazhar Pasha. Mazhar thereafter became the heritable family name. ${ }^{34}$

In the obituaries I surveyed, such matronyms would disappear by the mid-twentieth century, as would the feminine endings of adjectival alqab. For example, female 
members of the family of 'A'isha al-Taymuriyya, the famous female poet, had their names masculinised, marking the transformation of descriptive monikers into heritable patronyms. ${ }^{35}$ Although this would seem to support Scott's argument- that the ever-expanding state bureaucracy made its subjects individually and legally identifiable (taxable, prosecutable, numerable, etc.) by fixing their names as heritable patronyms - the obituaries suggest that there might have been other dynamics at work as well. The process of adopting heritable patronyms became visible in obituaries before it became compulsory by law, suggesting that there were other reasons that individuals abandoned the local and customary ways of self-identification and adopted, rather than were forced to adopt, these names. It invites us to think about how bourgeois family notions were becoming dominant at the turn of the twentieth century, as individuals wanted to appear related to one another for purposes of property, propriety and inheritance.

Obituaries are a valuable tool with which to chart the endurance of class power, and to highlight longue durée social formations that might otherwise remain invisible were one to attempt to trace them through surnames alone. As a recent sociological study has shown, in contexts as diverse as Qing China, medieval Britain and the contemporary United States, where heritable patronyms are common, 'surnames turn out to be a surprisingly powerful instrument for measuring social mobility'. ${ }^{36}$ For a historian attempting to understand social relations and class mobility in Egypt, the absence of heritable patronyms, for a large part of the country's modern history, can prove frustrating. Yet obituaries can do the work of surnames; for instance, using obituaries as source, the historian Samir Raafat was able to challenge Robert Springborg's study of Egyptian families in politics. ${ }^{37}$ Raafat examined the same family as Springborg did, but was able to construct a genealogy, and by extension a social history, that was far longer than that presented by his predecessor. ${ }^{38}$ Because Springborg imposed an ahistorical notion of family - narrowly limited to those that adopted a single patronym, 'Marei' - he was unable to see connections with previous generations that did not share the same name or form of identification.

What appeared in Springborg's account as the story of a family that was 'made' by 
the republican regime of the Nasser years appears in Raafat's account as the continuation of a three hundred year trajectory. Through his use of the obituary, Raafat demonstrates the remarkable tenacity of the family, showing that it was able to reinvent itself across, and survive, moments of political rupture, such as the rise of Mehmed Ali or the 1952 coup, rather than be produced by them. The family's longevity far exceeded that of any single political regime, and Raafat's account makes it clear that its history cannot be narrated according to the rhythms of changing regimes and high politics alone. Raafat thereby questions the very utility of narrating Egyptian history around these dramatic moments of political rupture. But if the obituary is useful to the historian for the way it demonstrates the resilience and endurance of a single family's social status, property and power, it must also have been useful to those who composed it. If the assignation of names by state officials was resented for erasing men's origins, then the obituary-with its genealogical logic — was a means by which individuals overcame this measure. With no heritable patronym to immediately denote one's status, genealogically ornate obituaries situated their readers and writers within the horizontal landscape of Egyptian elites.

At the Egyptian Conference of 1911, the 'harmful' habit of obituary writing was denounced as damaging to the economy and the moral fabric of the nation. ${ }^{39}$ Facing an audience of Egypt's largely Muslim elite politicians and intellectuals, a speaker condemned a litany of dangerous death rituals. Misguided Muslims, in an act of cultural miscegenation, had adopted the crass customs of their Coptic and ancient ancestors. Citing Herodotus, he explained how rituals such as throwing mud on one's face, tearing clothes during lamentations and building elaborate cenotaphs had been inherited from the ancient Egyptian 'pagans'. ${ }^{40}$ Although it was women that were most guilty of these sins, he blamed their effete husbands for failing to prevent them. Such morally depraved and superfluous practices distracted from the ritual prayers (janaza) that the faith prescribed. Equally 'un-Islamic' was the novel innovation of writing obituaries, which sowed social discontent. 'Disloyal' and 'lazy' Egyptians now thought it sufficient to publish a newspaper note of condolence, instead of participating in the religiously obligatory practice of ritual prayer, causing bitterness and animosity between them and the family of the deceased. ${ }^{41}$ The obituary was 
single-handedly responsible for tearing apart the delicate social fabric that had bound Egypt's good Muslims together.

Beyond the moral cost, the speaker objected to the material burden that death rituals levied on Egyptians. According to the Ministry of Health's calculations, the total expenditure on mourning rituals among Egyptians was in excess of one million Egyptian pounds in 1909 alone. ${ }^{42}$ Families slaughtered cows in honour of the dead, paid hired lamenters and erected cenotaphs against the prohibitions of Islamic law. The writing of obituaries and the telegramming of condolences (the expenses for which were included in the one million pound figure) were profligate practices that ought to be eliminated. Similar condemnations have resurfaced more recently: after the 2011 uprising, a critic ridiculed Egyptian state bureaucrats for illegally publishing, at government expense, a thousand obituaries in a year, squandering five million Egyptian pounds in taxpayer money. ${ }^{43}$ The font size of the minister's name giving condolences dwarfed that of the deceased.

In face of such moral decay, the speaker at the Egyptian Conference found hope in the fact that a recent spate of funerals had been conducted in perfect accordance with God's law. The first was held by Muhammad 'Abduh for his mother in $1895 .{ }^{44}$ When she died, the speaker explained,

He informed no one. No one came to perform the burial rituals except those who learnt about it coincidentally. After the burial he distracted himself from the calamity ... by strolling about and by physical exercise ... receiving no condolers at home, and putting no advertisement in the papers except a note to thank those who attended the burial and those that wrote to him. He advertised that there will be no rituals after the burial. Others who abandoned similar innovations include his Excellency Sa'd Zaghlul, when his mother died, and Riyad Pasha and Ahmad Bey Taymur. ${ }^{45}$

The note of thanks that 'Abduh published in al-Ahram suggests that it was his illness, rather than his desire to strip religion of superstition, that prevented him from receiving condolences. ${ }^{46}$ Regardless, 'Abduh did not publish an obituary for his mother. By contrast, the obituary of Zaghlul's mother, published in December 1898, 
is one of the most remarkable examples of the genre. On the day of her passing, a standard death notice was printed in multiple newspapers. ${ }^{47}$ Two days later an obituary, unprecedented in length, was published augmenting the first. ${ }^{48}$ After some investigation, the editors of al-Mu'ayyad thought it instructive to publish further details about the actual death and funeral of the deceased. Probably written by a man, the obituary gave a novelistic account of the deceased's 'good death' ${ }^{49}$ The author described how Zaghlul's ill mother, Maryam, began to sense that her demise was imminent. She came to Cairo from her 'backwards' home village not to seek treatment, they emphasized, but instead to avoid the death rituals, lamenting and wailing which the ignorant peasants of her village would have conducted 'for a woman as great as her', but which ran contrary to God's law. ${ }^{50}$ Shortly before she died, Maryam explained to her family her desire to avoid these ungodly traditions.

Some days later, 'God gave her what she had desired', and the funeral was conducted in silence with neither wailing nor lamentation, reported al-Mu'ayyad. The hushed procession was led by cavalry policemen, who recited verses from the Qur'an under their breath, fearful of upsetting the deceased. Followed by men holding copies of the Prophet's collected sayings, the crowd was seen but not heard. Although some mourners accidentally showed up at the procession bearing the customary incense burners, the incense was removed from the censers and replaced with fragrant basil. It was feared that burning incense, although in line with the dictates of tradition, might be considered to be against the dictates of God by Maryam's family, who were keen to follow her wish to strip religion from the cultural impurities with which it had been contaminated.

The picturesque account in al-Mu'ayyad continues for several columns, detailing the route taken by the cortège and the mourners from house to cemetery, as well as the names of those in attendance - the domain's most prominent religious and political authorities. But it is particularly notable for the scrutiny to which it subjects the rituals of death and burial, and for conveying the sense that there is such a thing as a 'good death', a novelty acknowledged by the authors themselves in the text. As they write,

It must be recalled here that this scene had been without equal and unprecedented in its compliance with the Noble Law of God. ... No voices 
were heard in it of those shouting ... prayers. ... Nor were the voices of female wailers and lamenters heard. ... No smoke was seen rising from the incense burners, for there was no fire inside it. All was done in accordance with ... the lofty Law of God, which is what she ... had hoped for and what she feared might not happen were she to die in the countryside. ${ }^{51}$

'Had all women been like her', the author hypothesises, 'they would have surely become superior to men'. Justifying the length of the obituary, the unnamed reporter hoped that 'her moral qualities would make her into a model' for all people, but especially 'the lowest of classes' ${ }^{52}$ What is striking here-and unlike most texts about women from the time - is that it was not Maryam's status as a nurturing mother of nation-building sons that was emphasised (the fame and notoriety her sons would achieve still lay ahead in the future), but rather her own virtue. By submitting to God in death, Maryam was worthy of emulation in life.

The proscriptions against wailing, throwing mud and burning incense that the obituary outlined were hardly new; al-Maqrizi had described the violent legal measures taken against such immoral practices in the early fifteenth century. ${ }^{53}$ What was new was the obituary's novelistic description of the deceased's interiority, motivations and, most of all, her desires. By portraying Maryam as a self-governing, morally free agent who undertook a rational choice - rather than as the victim of a law tyrannically imposed upon her - the obituary communicated the fairly novel notion that ethical decisions should be exclusively the result of the private and autonomous decision of an individual, and not the product of law, tradition or custom imposed from outside. This reflected the novel sensibilities of secularity, as Talal Asad has forcefully argued, that emerged in the late nineteenth century. ${ }^{54}$

This highly literary obituary also communicated the modernist idea that 'religion' had been corrupted by 'culture', a trope that was salient among many reformist thinkers in the late nineteenth century. Only by separating the two - and ridding the former of the impurities sullying the latter-would the good Muslim attain the ethical ideal to which she aspired. The obituary shows how the pursuit of such modernist ideals, which sought to remake the Muslim ethical subject, were communicated, mediated, and disseminated in everyday texts, rather than through the more abstract and 
speculative theological treatises that are usually considered in intellectual histories of modernist Islam.

Unlike the marble cenotaphs of Cairo's sprawling necropolises, obituaries seem as ephemeral as the paper on which they were printed. Read, crumpled up, and thrown away, they were transient, much like human life itself. At best, an obituary might have been clipped from the paper, stashed in a drawer and forgotten. It was this impermanence that provoked anxieties over the wasteful expense of publishing death notices as acts of commemoration. Yet today, all of the obituaries from every issue of al-Ahram since 1876 are online and easily accessible to the public. It is a fertile resource for the historian, and an unexpected validation of the impulse to write obituaries in the first place - a digital immortality that their authors would never have imagined. It is up to future generations of historians of Egypt to turn to the back pages and decipher their stories.

\footnotetext{
1 'Snatched by Destiny's Hand' (ikhtatafat yad al-manun) is one of the most common opening lines of turn of the century Egyptian obituaries.

${ }^{2}$ Rodenbeck, Cairo: The City Victorious, 89.

${ }^{3}$ Ibid.

${ }^{4}$ Burton, 'Thinking beyond the Boundaries: Empire, Feminism and the Domains of History', 66-8. Obituaries have been an integral source for the creation of family trees on the websites www.egy.com, http://bassatine.net and http://www.geni.net.

${ }^{5}$ Omar, 'The State of the Archive', 174-8.

${ }^{6}$ Di-Capua, Gatekeepers of the Arab Past, 111.

${ }^{7}$ Scott et al., 'The Production of Legal Identities', 4-44.

${ }^{8}$ The first female obituary was neither. Al-Ahram, 20 July 1877.

${ }^{9}$ For example, the Zaghluls' mother, Maryam, is named on her cenotaph but not in her obituary. See al-Ahram, 9 December 1898.

${ }^{10}$ Social categories such as afandiyya are entirely absent. Instead there are other categories such as the sometimes interchangeable $a^{\prime}$ yan and dhawat, and less familiar ones such as dhu al-amlak. See $a l$ Ahram, 10 Aug. 1926.
} 
${ }^{11}$ Al-Ahram, 5 Aug. 1876.

${ }^{12}$ Al-Ahram, 20 July 1877.

${ }^{13}$ Contrary to the rumour that revenue from obituaries allows al-Ahram to break even, the editor Hisham Qassim alleged that in 2010 alone the paper ran a multi-million pound deficit (personal comment).

${ }^{14}$ Al-Ahram, 8 May 1954.

${ }^{15}$ Given to author by al-Ahram in Apr. 2014.

${ }^{16}$ In the years after the 1952 coup, ancien régime individuals published ever more elaborate obituaries, to compensate in genealogy what they had lost in titles.

${ }^{17}$ Although the academic literature describes these categories not only as distinct but also antagonistic, in these first obituaries they appear fluid. See Hunter, Egypt under the Khedives, 80.

${ }^{18}$ Much like Benedict Anderson's 'print capitalism' allowed individuals to imagine belonging to a community larger than that of their immediate surroundings, the obituaries helped their readers and writers conceive of themselves as belonging to a horizontal category of individuals.

${ }^{19}$ More rarely, in some cases the names of adult men were omitted as well. See al-Ahram, 11 June 1895. In the one monograph which examines Egyptian obituaries, Mushira Eid deals with some of these gender issues in some detail. See Eid, The World of Obituaries.

${ }^{20}$ Al-Ahram, 3 Dec. 1973.

${ }^{21}$ Al-Ahram, 23 Mar. 1895.

${ }^{22}$ Al-Ahram, 26 Mar. 1895.

${ }^{23}$ Scott et al., 'The Production of Legal Identities', 4-44. See Fahmy, 'The Birth of the Secular Individual', 344- 348 for the link between the use of patronyms and the rise of the new Siyāsa Courts.

${ }^{24}$ See Türköz, 'Surname Narratives', 893-908.

${ }^{25}$ Endress, Islam, 142-5.

${ }^{26}$ The example of the famous nationalist "Abd al-Aziz al-Masri Pasha is instructive. He was known as al-Masri in Istanbul and by his Circassian tribal designation, Chapli, in Egypt.

${ }^{27}$ Fahmy, 'The Birth of the Secular Individual', 353.

${ }^{28}$ Guides for appropriate or beautiful combinations of names were published in the late nineteenth century. See al-Ahram, 15 and 16 Feb. 1877.

${ }^{29}$ Barakat, 'An Autobiography of H. E. the Late Fathalla Pacha', 17.

${ }^{30}$ Ibid.

${ }^{31}$ In other cases, it was parents, not schoolmasters, that assigned such names to their children. Isma 'il Sidqi Pasha's father, a state official, named him after the once-powerful court favourite Isma 'il Siddiq al-Muffatish. When al-Muffatish fell out of Khedivial favour and was summarily executed, the father changed his son's name to Ismai'1 Sidqi. See Badrawi, Ismail Sidqi, 1.

${ }^{32}$ Bahgat died in 1875. See also al-Ahram, 17 Dec. 1937. See also al-Ahram, 27 July 1987.

${ }^{33}$ Al-Ahram, 1 June 1960.

${ }^{34}$ Al-Ahram, 4 Feb. 1962, and al-Ahram, 30 April 1928.

${ }^{35}$ Al-Ahram, 26 May 1902. For the subsequent disappearance of feminised endings, see al-Ahram, 26 Oct. 1974.

${ }^{36}$ Clark et al., The Son Also Rises, 8.

${ }^{37}$ Springborg, Family, Power, and Politics in Egypt.

${ }^{38}$ Raafat, Privileged for Three Centuries. 
${ }^{39}$ Anonymous, Majmu 'at A 'mal al-Mu'tamar al-Masri al-Awal, 113-9. The speaker, Muhammad Bey Yusuf, was a lawyer that had defended the Egyptian victims of Dinshaway.

${ }^{40}$ Ibid., 113-4.

${ }^{41}$ Ibid., 115.

42 Ibid.

${ }^{43}$ Osman, 'Solace at the State's Expense', http://www.thecairoreview.com/tahrir-forum/solace-at-thestates-expense.

${ }^{44}$ Al-Ahram, 11 May 1895.

${ }^{45}$ Majmu 'at A 'mal al-Mu'tamar al-Misri al-Awal, 116.

${ }^{46}$ Al-Ahram, 11 May 1895.

${ }^{47}$ Al-Mu'ayyad, 8 Dec. 1898. See also al-Ahram, 9 Dec. 1898.

${ }^{48}$ Al-Mu 'ayyad, 10 Dec. 1898. In contrast to the 'good death', see al-Ahram, 29 Aug. 1902 for a 'bad death': the funeral of a morally depraved and drunken 'Negress', undoubtedly a member of the lower classes that the reporters in al-Mu'ayyad thought so needing of moral betterment. The deceased's wobbling cortège had led her misguided and superstitious mourners to declare her a saint on the spot.

${ }^{49}$ This is also right at the period when, as Marilyn Booth argues, men were beginning to write women's histories. See Booth, Classes of Ladies, 323-5.

50 Ibid.

51 Ibid.

52 Ibid.

${ }^{53}$ Al-Maqrizi, al-Suluk, describing events of 822 AH/1419 CE, cited in Fahmy, 'Food, Hisba and Chemistry', 22.

${ }^{54}$ Asad, Formations of the Secular, 236-56. 


\section{Bibliography}

Al-Ahram digital archive, http://digital.ahram.org.eg/youmy/EventBrowes2.aspx, accessed 3 Oct. 2011-20 Apr. 2014.

Al-Mu'ayyad digital archive, http://zefys.staatsbibliothekberlin.de/kalender/auswahl/date/1896-1118/26687665/, accessed Jul.-Aug. 2013.

Anderson, B., Imagined Communities: Reflections on the Origin and Spread of Nationalism (London: Verso, 2006).

Anonymous, Majmu'at A 'mal al-Mu'tamar al-Masri al-Awal (Cairo, 1911).

Asad, T. Formations of the Secular: Christianity, Islam, Modernity (Stanford: Stanford University Press, 2003). .

Badrawi, M., Ismail Sidqi, 1875-1950: Pragmatism and Vision (Surrey, UK: Curzon Press, 1996).

Barakat, F., 'An Autobiography of H. E. the Late Fathalla Pacha' (unpublished, Cairo, 1933).

Booth, M., May Her Likes Be Multiplied: Biography and Gender Politics in Egypt (California: University of California Press, 2001).

Classes of Ladies of Cloistered Spaces: Writing Feminist History through Biography in Finde-Siecle Egypt (Edinburgh: Edinburgh University Press, 2015).

Burton, A., 'Thinking beyond the Boundaries: Empire, Feminism and the Domains of History', Social History, 26/1 (2001): 60-71.

Cherena Pacheco, Y. M., 'What's in a Name? Retention and Loss of the Maternal Surname', in R. Delgado and J. Stefancic (eds.), The Latino/a Condition: A Critical Reader (New York: NYU Press, 1998).

Clark, G., The Son Also Rises: Surnames and the History of Social Mobility (Princeton, NJ: Princeton University Press, 2014).

Di-Capua, Y., Gatekeepers of the Arab Past: Historians and History Writing in Twentieth-Century Egypt (Berkeley: University of California Press, 2009).

Eid, M., The World of Obituaries: Gender Across Culture and Time (Detroit: Wayne State University Press, 2002).

Elshakry, M., Reading Darwin in Arabic, 1860-1950 (Chicago: University of Chicago Press, 2013). 
Endress, G., Islam: An Historical Introduction (New York: Columbia University Press 2002).

Fahmy, K., 'Food, Hisba and Chemistry’ (unpublished paper).

'Birth of the 'Secular' Individual: Medical and Legal Methods of Identification in Nineteenth Century Egypt' in K. Breckenridge and S. Szrester (eds.) Registration and Recognition: Documenting the Person in World History (Oxford: Oxford University Press, 2012).

Gasper, M. E., The Politics of Representation: Publics, Peasants and Islam (Stanford, CA: Stanford University Press, 2008).

Hunter, R., Egypt under the Khedives, 1805-1879: From Household Government to Modern Bureaucracy (Cairo: American University in Cairo Press, 1999).

Lockman, Z., 'Imagining the Working Class: Culture, Nationalism and Class Formation in Egypt, 1899-1914,' Poetics Today, 15/2 (1994): 157-90.

Al-Maqrizi, T., al-Mawa 'iz wa-l-I'tibar bi-Dhikr al-Khitat wa-l-Athar (Cairo: Matba'at Bulaq, 1853).

Minkin, S., 'History from Six-feet Below: Death Studies and the Field of Modern Middle East History', History Compass, 11/8 (2013): 632-46.

Mitchell, T., 'Society, Economy and the State Effect', in G. Steinmetz (ed.), State/Culture: StateFormation after the Cultural Turn (Ithaca, NY: Cornell University Press, 1999), 76-97.

Mubarak, 'Ali, al-Khitat al-Tawfiqiyya al-Jadida (Cairo: Matba'at Bulaq, 1887).

Omar, H. A. H., 'The State of the Archive', in W. Carruthers (ed.), Histories of Egyptology: Interdisciplinary Measures (London: Routledge, 2014), 174-84.

Osman, M., 'Solace at the State's Expense', http://www.thecairoreview.com/tahrir-forum/solace-atthe-states-expense, accessed 22 Apr. 2016.

Raafat, S., Egy.com: Cairo's Recollections Online!, www.egy.com, accessed 11 Mar. 2014.

ב, Bassatine News, http://bassatine.net, accessed 11 Mar. 2014.

— Privileged for Three Centuries: The House of Chamsi (Cairo, 2011).

Reynolds, D. F., Interpreting the Self: Autobiography in the Arabic Literary Tradition (Berkeley: University of California Press, 2001). 
Rodenbeck, M., Cairo: The City Victorious (London: Picador, 1999).

Ryzova, L., 'My Notepad Is My Friend: Efendis and the Act of Writing in Modern Egypt', Maghreb Review, 32/4 (2007): 323-48.

The Age of the Efendiyya: Passages to Modernity in National-Colonial Egypt (Oxford: Oxford University Press, 2014).

Scott, J. C., J. Tehranian, and J. Mathias, 'The Production of Legal Identities Proper to States: The Case of the Permanent Family Surname', Comparative Studies in Society and History, 44/1 (2002): 444.

Springborg, R., Family, Power, and Politics in Egypt: Sayed Bey Marei-His Clan, Clients, and Cohorts (Philadelphia: University of Pennsylvania Press, 1982).

Türköz, M., 'Surname Narratives and the State-Society Boundary: Memories of Turkey's Family Name Law of 1934', Middle Eastern Studies, 43/6 (2007): 893-908.

Tülüveli, G., 'Honorific Titles in Ottoman Parlance: a Reevaluation' in International Journal of Turkish Studies 11/1-2 (2005): 17-27.

Yilmaz, H., Becoming Turkish: Nationalist Reforms and Cultural Negotiations in Early Republican Turkey, 1923-1945 (Syracuse, NY: Syracuse University Press, 2013). 